\title{
Comparative Study of Different Drying Methods for Drying of Blanched Fenugreek Leaves
}

\author{
Balwan Singh ${ }^{1}$, Vijay K. Singh ${ }^{1}$ and Sunder Singh ${ }^{2}$ \\ ${ }^{1}$ Department of Processing \& Food Engineering, CCSHAU, Hisar, India \\ ${ }^{2}$ Department of Botany, MDU, Rohtak, India \\ *Corresponding author
}

A B S T R A C T

\begin{tabular}{|l|}
\hline Key w o r d s \\
Different drying \\
methods, \\
$\begin{array}{l}\text { Fenugreek, } \\
\text { drying }\end{array}$ \\
\hline Article Info \\
\hline $\begin{array}{l}\text { Accepted: } \\
\text { 10 December } 2018 \\
\text { Available Online: } \\
\text { 10 January } 2019\end{array}$ \\
\hline \hline
\end{tabular}

\section{Introduction}

Fenugreek is one of the oldest cultivated spice crops of the world and grown for its medicinal value and forage in India (Sweta et al., 2017). Fenugreek is also known as 'Kasuri Methi'. It is a very ancient spice which is used for flavouring various dishes. These leaves are bitter in taste, when added to any recipe it will surely titillate your taste bud. They are also known as protective food, which reflect their significance in supply of vital nutrients, essential for our health. In addition, they provide dietary fibres which aids in proper digestive function. Green leafy vegetables are rich source of vitamin $\mathrm{A}$ and $\mathrm{C}$ and mineral such as calcium, iron, phosphorus and potassium. The Fenugreek (Trigonella foenumgraecum L.) is mainly grown in Northern India. The leaves and young pods are used as vegetables and the seed as condiments. It has also some medicinal value which prevents constipation, removes indigestion, stimulates the spleen and the liver, and is appetizing and diuretic. The leaves are quite rich in protein, minerals and vitamin $\mathrm{C}$. Fenugreek is considered to be a native of Eastern Europe and Ethiopia and is also found growing wild in North-Western India. It belongs to the family Leguminoseae, genus 
Trigonella and species foenum-graceum. The Kasuri or Chama methi belongs to the same genus but species corniculata. These two differ in their growth habits. The common methi is quick growing and produces upright shorts and the Kasuri methi, is slow growing initially, and remain in a rosette condition during most of its vegetative growth period. Kinetics of fenugreek drying on different trays of an indirect solar dryer was examined so as to increase its shelf life (Shrivastava, 2017).

Fenugreek is a popular green leafy vegetable in India. Being a seasonal crop, it is available in plenty at lower cost during winter season (Patil et al., 1978) and therefore, can be dehydrated to make it available in off-season. It produced the quality of dehydrated product is maintained to be acceptable. In fact dehydration is the method of choice for vegetables (Mandhyan et al., 1988). Green leafy vegetables are highly perishable due to their high moisture content ranges from (80$92 \%$ w.b) and available for very short period of time. This creates a considerable gap between demand and non-availability. The storage life of green fenugreek is extremely short and varies form few hours to 2-3 days depending upon the temperature and the relative humidity of the storage condition. In proper post harvest handling leads to the loss of large amount (around 32\%) of vegetables. Due to its high perishability and round the year demand almost it needs to be processed into dehydrated form. The various methods of dehydrated green leafy vegetables are sun drying shade drying, fluidized bed drying and tray drying etc. These drying methods need to be evaluated for drying of different vegetable so that there is a minimum damage to the vegetables in terms of quality. The moisture content and drying rate were affected by drying air temperature. Increase in drying air temperature caused decrease in drying time and an increase in drying rate (Kaur et al.,
2018). Keeping this in view the above facts in mind the present study is carried out to standardise different drying methods for drying of fenugreek leaves (Methi) and study the storability of the dried product at ambient temperature.

\section{Materials and Methods}

The leaves of Kasuri fenugreek (Trigonella foenum graecum L.) were procured form the Arya Agricultural farm, Balsamand for conducting the present studies. The experiments were conducted in the Department of Processing and Food Engineering, COAE\&T, CS HAU Hisar, experiment to dry fenugreek leaves in different dryers and methods. The quality analysis of dried fenugreek in terms of chlorophyll content, $\mathrm{Ca}, \mathrm{Fe}$, ascorbic acid, colour, taste and appearance was performed as per standard procedure. Pre-drying treatment, blanching was carried using solution of $0.5 \%$ $\mathrm{KMS}+0.1$ percent Mgo +0.1 percent $\mathrm{NaHCO} 3$ was heated at $800 \mathrm{C}$ and the leaves of fenugreek were dipped in it for 3-4 min. Free water was removed by blotting.

Moisture content of freshly harvested fenugreek leaves was measured just before the start of the experiment. Standard hot air oven method used for the leafy vegetables (AOAC, 1970 and ASAE Standard, 1991) was employed for moisture content determination of the fenugreek leaves. The percent moisture content was determined using flowing equations.

Moisture content $(w b)=\frac{W_{1}-W_{2}}{W_{2}} \times 100$

Where, $\mathrm{W}_{1}$ and $\mathrm{W}_{2}=$ Initial and final weight of the samples, $\mathrm{g}$

Chlorophyll content of fenugreek leaves was determined as per method of Arnon (1949) 
and AOAC (1990). Available iron was extracted by D.T.P.A. as suggested by Lindsay 1978. Ascorbic acid was determined by the method of AOAC (1990). Rehydration ratio of dried leaves was measured by method described by Pruthi et al., (1976). Fenugreek leaves stems and soil was removed by washing in clean water. Initial moisture content of prepared samples of fenugreek leaves was determined before the drying studies by standard hot air oven method. Sun drying, shade drying, fluidized bed 40, 50, $60^{\circ} \mathrm{C}$ drying, tray drying at $40,50,60^{\circ} \mathrm{C}$ were conducted. The drying experiments were replicated thrice. The observation of weight loss was taken at a regular interval of $1 \mathrm{hrs}$. The samples were dried till the moisture content comes to 6-12\% (d.b). After drying, the sample was cooled in desiccators and then seated in a polyethylene bags for quality analysis and storage. The dried fenugreek leaves were evaluated to determine quality characteristics in terms of colour, appearance, taste and overall acceptability. Sensory evolution was carried out using 6-point hedonic scale (Amerine et al., 1985).

\section{Results and Discussion}

Fenugreek (Trigonella foenum graecum L.) is an important green leafy vegetable commonly grown in many part of India. Fresh fenugreek contains very high moisture content (80-92\% wb). To increase the storability of fenugreek leaves, it was to be dried to safe moisture content of $8-12 \%$ (d.b). The chlorophyll content was $(0.70 \mathrm{mg} / 100 \mathrm{~g})$ ascorbic acid $(0.54 \mathrm{mg} / 100 \mathrm{~g})$, calcium and iron content (360 $\mathrm{mg} / 100 \mathrm{~g})$, (17.2 mg/100g). Several methods were used for drying fenugreek leaves. Different drying methods affect the quality of the dried products. Several parameters influence the time required to dry the product to the desired moisture content in different methods of drying. These include initials moisture content, final moisture content of the product, type of dryer, drying method, ambient atmospheric conditions and drying air temperature. In the present study experiments were conducted to evaluate different types of dryers and drying methods such as open sun drying, drying in shade, drying in fluidized bed and drying in tray drier. The effect of dryer and drying method on the chemical quality i.e. chlorophyll content, ascorbic acid content, calcium and iron content and physical qualities such as colour, taste, appearance and over all acceptability was investigated. Time taken to bring the moisture content of dehydrated fenugreek leaves to storage moisture content in different drying methods and dryer was also determined.

\section{Dehydration characteristics of blanched treatment of fenugreek leaves}

The data with respect to chlorophyll were reached and presented in table 1 . The data revels that open sun dried sample had significantly lower chlorophyll content $(0.38 \mathrm{mg} / 100 \mathrm{~g})$ was compared to shade dried $(0.43 \mathrm{mg} / 100 \mathrm{~g})$ and fluidized bed dried sample at different temperature $40,50,60^{\circ} \mathrm{C}$, $(0.35 \mathrm{mg} / 100 \mathrm{~g}), \quad(0.36 \mathrm{mg} / 100 \mathrm{~g}), \quad(0.35 \mathrm{mg} /$ $100 \mathrm{~g})$, and tray dried sample was (0.40mg/100g), (0.40mg/100g), (0.40mg/ $100 \mathrm{~g})$. During storage, that total chlorophyll was significantly reduced from 0th $(0.41 \mathrm{mg} / 100 \mathrm{~g})$ to $60 \mathrm{th}(0.36 \mathrm{mg} / 100 \mathrm{~g})$ days. The maximum total chlorophyll was obtained in case of shade-dried sample. The data on ascorbic acid content of dehydrated fenugreek leaves are presented in table 2 . The result indicates that the open sun dried sample had significantly lower ascorbic acid content $(0.32 \mathrm{mg} / 100 \mathrm{~g})$ as compared to shade dried $(0.36 \mathrm{mg} / 100 \mathrm{~g})$, fluidized bed dried sample at $40, \quad 50, \quad 60^{\circ} \mathrm{C}$ was at $(0.29 \mathrm{mg} / 100 \mathrm{~g})$, $(0.29 \mathrm{mg} / 100 \mathrm{~g}),(0.28 \mathrm{mg} / 100 \mathrm{~g})$ and tray dried sample at $40,50,60^{\circ} \mathrm{C}$ was $(0.31 \mathrm{mg} / 100 \mathrm{~g})$, $(0.32 \mathrm{mg} / 100 \mathrm{~g}),(0.36 \mathrm{mg} / 100 \mathrm{~g})$. 
Table.1 Effect of drying method and storage time on the chlorophyll content the dehydrated fenugreek leaves

\begin{tabular}{|l|l|l|l|r|}
\hline S. & Drying methods & \multicolumn{2}{l|}{ Storage period (days) } & \multicolumn{1}{l|}{$\begin{array}{l}\text { Over } \\
\text { mean }\end{array}$} \\
\cline { 3 - 4 } No. & & 0 & 60 & 0.38 \\
\hline 1. & Sun Drying & 0.41 & 0.36 & 0.43 \\
\hline 2. & Shade Drying & 0.45 & 0.42 & 0.35 \\
\hline 3. & Fluidized bed drying at $40^{\circ} \mathrm{C}$ & 0.39 & 0.32 & 0.36 \\
\hline 4. & Fluidized bed drying at $50^{\circ} \mathrm{C}$ & 0.35 & 0.34 & 0.35 \\
\hline 5. & Fluidized bed drying at $60^{\circ} \mathrm{C}$ & 0.36 & 0.34 & 0.40 \\
\hline 6. & Tray drying at $40^{\circ} \mathrm{C}$ & 0.42 & 0.38 & 0.40 \\
\hline 7. & Tray drying at $50^{\circ} \mathrm{C}$ & 043 & 0.40 & 0.40 \\
\hline 8. & Tray drying at $60^{\circ} \mathrm{C}$ & 043 & 0.38 & \\
\hline & Over all mean & 0.41 & 0.36 & \\
\hline
\end{tabular}

Table.2 Effect of drying methods and storage time on the ascorbic acid content $(\mathrm{mg} / 100 \mathrm{~g}$ of dehydrated fenugreek leaves

\begin{tabular}{|l|l|c|c|c|}
\hline S. & Drying methods & Storage period (days) & Over all mean \\
\cline { 3 - 5 } No. & & 0 & 60 & \\
\hline 1. & Sun Drying & 0.35 & 0.29 & 0.32 \\
\hline 2. & Shade Drying & 0.38 & 0.35 & 0.36 \\
\hline 3. & Fluidized bed drying at $40^{\circ} \mathrm{C}$ & 0.32 & 0.27 & 0.29 \\
\hline 4. & Fluidized bed drying at $50^{\circ} \mathrm{C}$ & 0.32 & 0.26 & 0.29 \\
\hline 5. & Fluidized bed drying at $60^{\circ} \mathrm{C}$ & 0.30 & 0.26 & 0.28 \\
\hline 6. & Tray drying at $40^{\circ} \mathrm{C}$ & 0.34 & 0.28 & 0.31 \\
\hline 7. & Tray drying at $50^{\circ} \mathrm{C}$ & 0.35 & 0.30 & 0.32 \\
\hline 8. & Tray drying at $60^{\circ} \mathrm{C}$ & 0.34 & 0.28 & 0.36 \\
\hline & Over all mean & 0.34 & 0.29 & \\
\hline
\end{tabular}

Table.3 Effect of drying methods and storage time on the calcium content $(\mathrm{mg} / 100 \mathrm{~g})$ of the dehydrated fenugreek leaves

\begin{tabular}{|l|l|l|l|c|}
\hline \multirow{2}{*}{$\begin{array}{l}\text { S. } \\
\text { No. }\end{array}$} & Drying methods & \multicolumn{2}{l|}{ Storage period (days) } & Over all mean \\
\cline { 3 - 4 } & & 0 & 60 & 251 \\
\hline 1. & Sun Drying & 252 & 250 & 257 \\
\hline 2. & Shade Drying & 257 & 257 & 255 \\
\hline 3. & Fluidized bed drying at 400C & 256 & 254 & 256 \\
\hline 4. & Fluidized bed drying at 500C & 256 & 256 & 254 \\
\hline 5. & Fluidized bed drying at 600C & 255 & 254 & 254 \\
\hline 6. & Tray drying at 400C & 254 & 254 & 252 \\
\hline 7. & Tray drying at 500C & 253 & 252 & 256 \\
\hline 8. & Tray drying at 600C & 252 & 260 & \\
\hline & Over all mean & 254.3 & 254.6 & \\
\hline
\end{tabular}


Table.4 Effect of drying methods and storage time on the iron content $(\mathrm{mg} / 100 \mathrm{~g})$ of the dehydrated fenugreek leaves

\begin{tabular}{|l|l|l|l|l|}
\hline $\begin{array}{l}\text { S. } \\
\text { No. }\end{array}$ & Drying methods & \multicolumn{2}{l|}{ Storage period (days) } & \multirow{2}{*}{ Over all mean } \\
\cline { 2 - 4 } & & 0 & 60 & \\
\hline 1. & Sun Drying & 9.8 & 9.6 & 9.7 \\
\hline 2. & Shade Drying & 9.6 & 9.6 & 9.6 \\
\hline 3. & Fluidized bed drying at $40^{\circ} \mathrm{C}$ & 9.4 & 9.2 & 9.3 \\
\hline 4. & Fluidized bed drying at $50^{\circ} \mathrm{C}$ & 9.0 & 9.0 & 9.0 \\
\hline 5. & Fluidized bed drying at $60^{\circ} \mathrm{C}$ & 9.0 & 8.8 & 8.9 \\
\hline 6. & Tray drying at $40^{\circ} \mathrm{C}$ & 10.2 & 10.0 & 10.1 \\
\hline 7. & Tray drying at $50^{\circ} \mathrm{C}$ & 10.8 & 10.0 & 20.4 \\
\hline 8. & Tray drying at $60^{\circ} \mathrm{C}$ & 10.8 & 10.4 & 10.5 \\
\hline & Over all mean & 9.8 & 9.5 & \\
\hline
\end{tabular}

Table.5 Effect of drying methods and storage time on rehydration ratio of dehydrated fenugreek leaves

\begin{tabular}{|l|l|l|l|l|}
\hline S. & Drying methods & \multicolumn{2}{l|}{ Storage period (days) } & Over all mean \\
\cline { 3 - 4 } No. & & 0 & 60 & \\
\hline 1. & Sun Drying & 5.2 & 3.6 & 4.4 \\
\hline 2. & Shade Drying & 5.0 & 3.0 & 4.0 \\
\hline 3. & Fluidized bed drying at $40^{\circ} \mathrm{C}$ & 5.3 & 3.6 & 4.4 \\
\hline 4. & Fluidized bed drying at $50^{\circ} \mathrm{C}$ & 5.2 & 4.0 & 4.6 \\
\hline 5. & Fluidized bed drying at $60^{\circ} \mathrm{C}$ & 5.2 & 3.6 & 4.4 \\
\hline 6. & Tray drying at $40^{\circ} \mathrm{C}$ & 5.4 & 3.8 & 4.6 \\
\hline 7. & Tray drying at $50^{\circ} \mathrm{C}$ & 5.6 & 4.2 & 4.4 \\
\hline 8. & Tray drying at $60^{\circ} \mathrm{C}$ & 5.6 & 3.8 & 4.7 \\
\hline Over all mean & 5.3 & 3.9 & \\
\hline
\end{tabular}

Table.6 Effect of Drying method and storage time on the overall acceptability of dehydrated fenugreek leaves

\begin{tabular}{|l|l|l|l|l|}
\hline $\begin{array}{l}\text { S. } \\
\text { No. }\end{array}$ & Drying methods & \multicolumn{2}{|l|}{ Storage period (days) } & Over all mean \\
\cline { 2 - 4 } 1. & Sun Drying & 5.0 & 60 & \\
\hline 2. & Shade Drying & 4.4 & 4.4 & 4.7 \\
\hline 3. & Fluidized bed drying at $40^{\circ} \mathrm{C}$ & 5.1 & 4.3 & 4.2 \\
\hline 4. & Fluidized bed drying at $50^{\circ} \mathrm{C}$ & 5.0 & 4.8 & 4.7 \\
\hline 5. & Fluidized bed drying at $60^{\circ} \mathrm{C}$ & 5.0 & 4.7 & 4.9 \\
\hline 6. & Tray drying at $40^{\circ} \mathrm{C}$ & 4.8 & 4.2 & 4.5 \\
\hline 7. & Tray drying at $50^{\circ} \mathrm{C}$ & 5.1 & 4.4 & 4.7 \\
\hline 8. & Tray drying at $60^{\circ} \mathrm{C}$ & 5.2 & 5.1 & 5.1 \\
\hline & Over all mean & 5.0 & 4.5 & \\
\hline
\end{tabular}


During storage, there was significant reduction of ascorbic acid. Maximum ascorbic acid content was obtained in case of shade-dried sample $\quad(0.36 \mathrm{mg} / 100 \mathrm{~g})$. Maximum loss of ascorbic acid in fenugreek leaves was during washing after cutting. Ascorbic acid decreases the length of storage of 60 days. This might be because of leaching of ascorbic acid in washing and blanching, which lead to distraction of ascorbic acid (Khader, 1988).

The data on calcium content of dehydrated fenugreek leaves are presented in table 3 . The results indicate that the method of open sun drying had non-significant effect on calcium content of fenugreek leaves. During storage, there was non- significant reduction of calcium content. Maximum calcium content was obtained in case of shade-dried fenugreek (257mg/100g).

The data on iron content of dehydrated leaves are presented in table 4 . The results indicate that the method of drying was significant effect on iron content of fenugreek leaves. During storage, there was non-significant effect on iron content was found. Maximum iron content was obtained in case of tray-dried fenugreek at $60^{\circ} \mathrm{C}(10.5 \mathrm{mg} / 100 \mathrm{~g})$.

Rehydration ratio of dehydrated fenugreek leaves presented in table 5 showed that the drying methods had non-significant effect on the rehydration ratio of fenugreek leaves. During storage period, the rehydration ratio was significantly reduced.

\section{Sensory evaluation of dried fenugreek leaves (blanched treatment)}

The dried fenugreek leaves from different drying methods was subjected to sensory evaluation by a panel of 8 judges following hedonic rating (6 points scale as described by Ranganna, 1981) test. Sensory score table 6 indicates that significant difference were observed in score of tray drier, shade drying, fluidized bed drying. In general, tray dried samples were superior to the other drying samples in terms of colour, taste, flavour and overall acceptability.

In conclusion, moisture content of fenugreek leaves from 6 to $12 \%(\mathrm{db})$ was suitable for storability. Tray drying at $60^{\circ} \mathrm{C}$ took minimum time $4 \mathrm{~h}$, followed by fluidized bed drying at $60^{\circ} \mathrm{C}$ took $6 \mathrm{~h}$, open sun dying took $8 \mathrm{~h}$ followed by shade drying was $12 \mathrm{~h}$ in blanched treatment sample. The dehydrated product was stored for 60 days and the effect of storage was also studied. The total chlorophyll content and ascorbic acid of the fenugreek leaves were significantly affected by drying methods as well as storage time. But there was non-significantly effect on drying methods and storage time on the calcium and iron content. There was no effect of drying methods on the rehydration ratio.

\section{References}

A.O.A.C. 1970. Official method of Analysis, 11th edition, Washington D.C., USA.

A.O.A.C. 1990 Official method of Analysis, 14th edition, Washington D.C

A.S.A.E. 1991. Standards, American Society of Agricultural Engineering. Engineering Practices and data. Mills road, St. Joseph, U.S.A.

Amerine, M.A., Pangorn, R.M. and Roessler, E.B. 1985. Principles of Sensory evaluation of foods Academic Press, London.

Arnon, D.I. 1949. Copper enzymes in isolated chloroplasts, polyphenol oxidase in Beta Vulgaris. PI. Physiol., 24(1): 9-15.

Kaur, R., Kumar, M., Gupta, O.P., Sharma, S. and Kumar, S. 2018. Drying Characteristics of Fenugreek and Its Computer Simulation for Automatic Operation. Int.J.Curr.Microbiol.App.Sci 
(2018) 7(3): 3275-3291.

Khader, V. 1988. Effect of working on nutrients losses of some common vegetable. The Andhra Agric. J. 33(4): 361-366.

Lindsay, W.L. and Norvell, W.A. 1978. Development of D.T.P.A. test for $\mathrm{Zn}$, $\mathrm{Fe}, \mathrm{Mn}$, and $\mathrm{Cu}$. Soil Sci. Soc., Americ. J. 42: 421-428.

Mandhyan, B.L., Abrol, C.M. and Tyagi, H.R. 1988. Dehydration characteristics of winter vegetables. J. Sci. Tech. 25(1): 20-22.

Patil, V.R., Kulkarni, O.K., Kulkarni Karuna and Ingle, U.M. 1978. Effect on blanching factors on quality and durability of sun dried and dehydrated fenugreek (methi). Ind. Fd Packer, 32(1): 41-49.
Pruthi, J.S., Singh, L.J., Kalbagh, S.S. and Lar, G. 1976. Effect of different method of dehydration and quality of garlic slices. Food Sci. 22(7): 32-36.

Ranganath, D.R. and Dubash, P.J. 1981. Loss of colour and vitamins on dehydration of vegetables. Ind. Fd. Packer., 35(4): 49.

Shrivastava, V. 2017. Kinetics of fenugreek drying in an indirect solar dryer. Journals of Heat Transfer Research, Volume 48, Issue 9. DOI: 10.1615/HeatTransRes.v48.i9.

Singh, S., Kumar, V., Singh, B.R. and Mishra, D.K. 2017. Studies on Drying Characteristics of Fenugreek Leaves under Cabinet Tray Dryer at Different Temperatures. Int. J. Pure App. Biosci. 5(6): 649-655.

\section{How to cite this article:}

Balwan Singh, Vijay K. Singh and Sunder Singh. 2019. Comparative Study of Different Drying Methods for Drying of Blanched Fenugreek Leaves. Int.J.Curr.Microbiol.App.Sci. 8(01): 10701076. doi: https://doi.org/10.20546/ijcmas.2019.801.116 